\title{
EXPERIMENTAL AND NUMERICAL INVESTIGATION OF THE FRICTIONAL FORCES IN EQUAL CHANNEL ANGULAR PRESSING
}

\author{
Mehdi ESKANDARZADE \\ Meysam NAJAFI ERSHADI
}

Received: 30.10.2020; revised: 08.03.2021; accepted: 28.03.2021

\begin{abstract}
The main limitation of the Equal Channel Angular Pressing (ECAP) is the very high required punching force for pushing the metallic sample to next channel. Frictional forces in ECAP process are responsible for very high required punching force. The participation of exit and entrance channels in total friction force has not been studied experimentally hitherto. Through the current study, two ECAP dies (1) with two channels (normal ECAP die) and (2) with only one channel (the exit channel was missed) were manufactured. Three-dimensional finite element analysis was conducted. The effect of the exit channel on the total punching force, sample geometry, and grain refinement rate were investigated experimentally and numerically. According to the results, the exit channel has a considerable effect on the amount of minimum required punching force and the grain refinement in ECAP process. The comparisons showed that, the trend of the results from experimental investigations were in good agreement with numerical analysis.
\end{abstract}

Keywords: Equal channel angular pressing, Friction, Punching force, Finite element method

\section{Eşit Kanal Açısal Presleme Sürtünme Kuvvetlerinin Deneysel ve Sayısal İncelenmesi}

Öz: Eşit Kanal Açısal Preslemenin (EKAP) temel sınırlaması, metal numuneyi kalıbın içine itmek için gereken yüksek zımbalama kuvvetidir. Gerekli yüksek zımbalama kuvvetinden EKAP sürecindeki sürtünme kuvvetleri sorumludur. Çıkış ve giriş kanallarının toplam sürtünme kuvvetine katılımı şimdiye kadar deneysel olarak incelenmemiştir. Bu çalışma sayesinde, iki kanallı (normal EKAP kalıbı) ve yalnızca bir kanallı (çıkış kanalı yok) olmak üzere iki EKAP kalıbı (1) (2) üretilmiştir. Üç boyutlu sonlu elemanlar analizi yapılmıştır. Çıkış kanalının toplam zımbalama kuvveti, numune geometrisi ve tane inceltme oranı üzerindeki etkisi deneysel ve sayısal olarak incelenmiştir. Sonuçlar, çıkış kanalının, EKAP sürecinde gerekli asgari zımbalama kuvveti miktarı ve tane inceltme üzerinde önemli bir etkiye sahip olduğunu göstermiştir. Yapılan karşılaştırmalar, deneysel araştırmaların sonuçlarının sayısal analiz ile uyumlu olduğunu göstermiştir.

Anahtar Kelimeler: Eşit kanal açısal presleme, Sürtünme, Zımbalama kuvveti, Sonlu eleman yöntemi

\footnotetext{
${ }^{*}$ Department of Mechanical Engineering, University of Mohaghegh Ardabili, Ardabil, Iran. P.C.: 5661745711 Phone: +989143541326; Fax: +98(45)31505941

Correspondence Author: Mehdi ESKANDARZADE (m.eskandarzade@uma.ac.ir)
} 


\section{INTRODUCTION}

Equal channel angular pressing (ECAP) die consists of entrance and exit channels with equal cross-sectional areas, intersecting at a specified angle varies between 90 and 120 degrees (Riazat and Faraji, 2015, Yoon, et. al. 2008, Xu, et. al. 2008). All of the fundamental and experimental parameters play an essential role in microstructural refinement during the pressing operation (Valiev and Langdon, 2006). During a die design and material selection steps of the ECAP process, it needed to have a rough estimate of the minimum required punching force (Nagasekhar, et. al. 2009). It is also important to understand the effect of die geometry and processing parameters on the deformation behavior, strain distribution and punch force (Agwa, et. al. 2016). Punching forces considerably could be influenced by the channel angle, material type and the sample geometry, where the greatest amount of punching force during the ECAP process is dissipated by frictional forces between the sample and the channels in the ECAP die (Cai, et. al. 2011). The characteristics of ECAP products are largely influenced by process routes and process parameters including die geometries, friction conditions and so on. Those factors especially affect the homogeneous distribution of accumulated effective strain in the workpiece (Salleh, et. al. 2018).

Higuera-Cobos and Cabrera (2013) correlated electrical properties with the associated energy resulted from the defects induced by ECAP on a sample and showed that the stored energy rises by increasing ECAP deformation. By understanding the grain morphology, it is possible to characterize the grain size homogeneity and estimate the structural parameters related to the physical properties of the material. In addition to punching force, many other parameters of the ECAP process such as strain homogeneity and material flow regime are affected by friction conditions (Ko and Shin, 2011). Patil, et. al. (2008) and Djavanroodi and Ebrahimi (2010) have used finite element analysis in order to investigate the effect of the friction coefficient between a sample and the ECAP channel on the inhomogeneity of the strain and strain distribution in a sample. Besides, the effect of friction value on the results of numerical analysis of the ECAP process was investigated in a work by Balasundar and Raghu (2010).

Souza, et. al. (2016) have used finite element model to predict the coefficient of friction in ECAP process numerically. Moreover, Cai, et. al. (2011) showed that by any increment in friction coefficient, the average effective strain remains constant, while the uniformity of effective strain is decreased. Furthermore, the interdependence between channel angle, corner angle and work hardening rate has been detected in a study by Dumoulin and Roven (2005). They found that the homogeneity increases by enhancing the friction. Eivani and Taheri (2008) in a research drew out that strain values decrease with increasing die angle and friction coefficient. Moreover, he has determined a critical value for friction coefficient, where if the friction coefficient is being higher than the critical friction value, a deformation zone and dead metal zone form, which consequently decreases the total strain. Agwa, et. al. (2016) also found that any changes in channel angle, corner angle and friction coefficient have significant influences on deformation behavior, strain coefficient of variance and punch load evolution. Riazat and Faraji (2015), Yoon, et. al. (2008), $\mathrm{Xu}$, et. al. (2008) and Eivani and Taheri (2008) indicated that by decreasing in sample diameter, the ratio of the friction to the total force increases significantly. They have also simulated the ECAP process for different sample sizes with and without friction and revealed that the friction plays a significant role in the amount of punching force. Nagasekhar, et. al. (2009) validated the FEM results for the effective strain variations by doing a comparison with the hardness measurements for different stages of the load-stroke curve of the ECAP process. Ultrasonic assisted ECAP is the method that is reported to be effective for reduction in friction in ECAP process and proposed by djavanroodi, et. al. (2013) and further studied by Eskandarzade, et. al. (2016).

As mentioned previously, the high value of the minimum required punching force is one of the limitations of the ECAP process that causes the restriction of the semi-industrial application 
of the process to relatively soft materials. The first step in calculating the minimum required punching force is finding the average friction coefficient between a die and sample. It has been shown that the friction coefficient is considerably influenced by temperature, sliding velocity, normal pressure, surface roughness and etc (Taşdelen and Y1lmaz, 2018). Although, there are few studies dedicated to find a friction coefficient via simulation (Valiev and Langdon, 2006), experimental methods are still the only reliable way for measuring the friction coefficient values (Nagasekhar, et. al. 2009, Agwa, et. al. 2016). While, the measurement of the friction coefficient can be helpful in order to calculate the minimum required force during the punching stage of the ECAP method, it is really difficult to identify the participation of the entrance and exit channel of the ECAP die in the total frictional forces (Ulutan, et. al. 2010).

In this study, two similar ECAP dies with and without exit channels were manufactured and the punching forces for pushing similar samples were recorded. The magnitude of the punching force, rate of refinement and the possible deformation of the final product after two ECAP processes were compared for two dies. The values for required punching force were recorded benefiting a tensile test machine. Furthermore, optical microscopy $(\mathrm{OM})$ was used to investigate the rate of microstructural refinement. Besides that, the geometrical deformation of the ECAP products was investigated, visually. The experimental results about the trend of variation in punching force by changing between two dies were in good agreement with the results from 3D finite element analysis.

\section{METHODOLOGY}

\subsection{System Description and Governing Equations}

Through the current study, two ECAP dies: I) including two channels (exit and entrance channels) and II) only one channel (entrance channel) exists, were manufactured. Figure 1 indicates these ECAP dies (Figure 1a, with exit channel) and (Figure 1b, without exit channel). The channels angle for both dies was set to be 90 degree and their hole's diameters were $10 \mathrm{~mm}$. The dies were made of AISI 4340 steel with about $710 \mathrm{MPa}$ yield strength and the channel surfaces in both dies were hardened to $60 \mathrm{HRC}$. The pure copper samples with dimensions of 70 $\mathrm{mm} \times 10 \mathrm{~mm}$ (length and diameter, respectively) were prepared and heat treated at $700{ }^{\circ} \mathrm{C}$ for one hour to relieve the effect of any possible previous cold workings on the samples. Subsequently, the samples were exposed to the ECAP process for two passes. The punching speed for both methods was set to be $5 \mathrm{~mm} / \mathrm{min}$ and the required punching force for each pass were recorded.

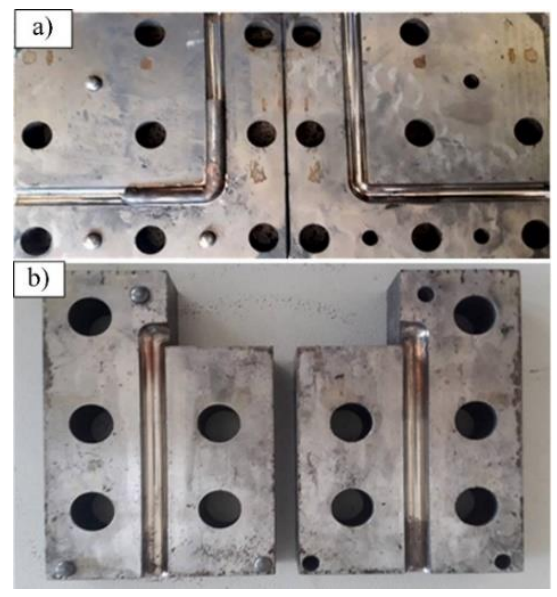

Figure 1:

(a) ECAP die with two channel; (b) ECAP die with only one channel. 
The 2D schematic of ECAP geometrics is presented in Figure 2. According to Figure 2 ECAP process consists of a die, two equal intersecting channels, one plunger for applying hydraulic pressure and metallic sample. The goal of processing materials in ECAP die is to produce ultrafine grains at the microstructures of the samples. The advantages of producing fine grain products was presented by Eskandarzade, et. al. (2017).

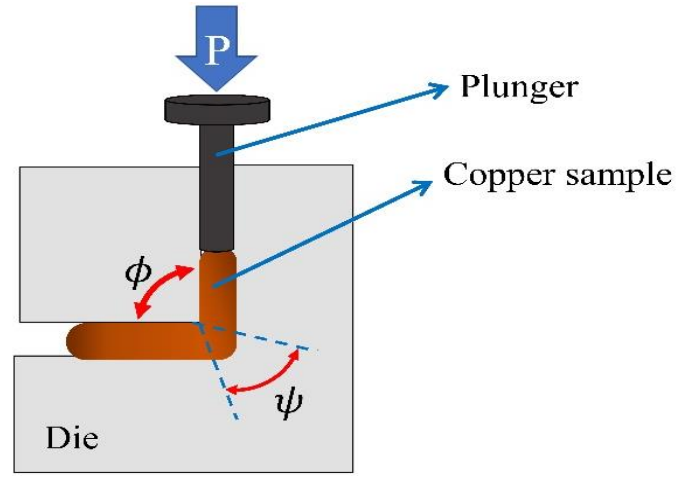

Figure 2:

$2 D$ illustration of the ECAP process.

In order to achieve ultrafine grains a sample should be pushed inside a vertical channel using a plunger to produce shear stress in turning sections of a sample. Figure 3 shows the experimental setup of this study. As it is clear from Figure 3 the hydraulic machine was used to produce pressure force on a ECAP ram. The S-type load cell equipped with force indicator was used to measure the amount of the applied load on a ECAP ram. Pressure forces cause a hydraulic pressure on a sample inside a die which helps maintaining the structural integrity of the sample. The local region of a sample which turns into a horizontal channel side exposes a severe shear stress and plastic deformation. The theoretical equivalent strain $\left(\varepsilon_{\text {eq }}\right)$ in this process can be estimated using an equation presented by Agarwal, et. al. (2020) as:

$$
\varepsilon_{e q}=\frac{N}{\sqrt{3}}\left[2 \cot \left(\frac{\phi+\psi}{2}\right)+\psi \operatorname{cosec}\left(\frac{\phi+\psi}{2}\right)\right]
$$




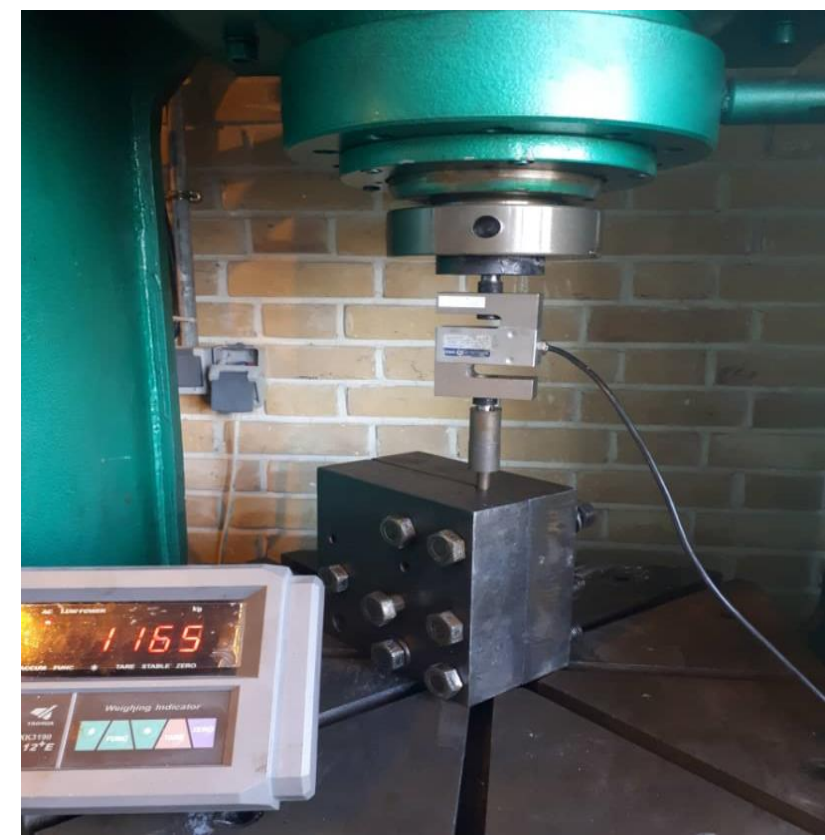

Figure 3:

Experimental setup of this study.

Where, $\mathrm{N}$ is number of passes, $\phi$ is the channel angle and $\psi$ is corner angle (which are shown in Figure 2). The required pressing force in ECAP process of the sample $(\mathrm{P})$ is expressed by (Djavanroodi and Ebrahimi, 2010):

$$
P=\tau_{0}(1+\mu)\left[2 \cot \left(\frac{\phi+\psi}{2}+\psi\right)\right]+4 \mu \tau_{0}\left(\frac{l_{i}+l_{o}}{w}\right)
$$

Where $\mu, w, \tau_{0}, l_{i}$ and $l_{o}$ represent the coefficient of friction, the channel width, shear strength, spot length of the sample in the entrance channel and spot length of the sample in the exit channel, respectively.

\subsection{Finite Element Method}

The three-dimensional finite element modelling of the process was performed in ABAQUS software. The punch and the die were modelled as rigid bodies; but the copper sample was simulated as a deformable body. The mechanical properties of the copper is assigned to model of sample. General contact algorithm with penalty formulation is employed to simulate the friction phenomena in the model. Linear element with reduced integration is used to mesh the sample. This type of element is more effective than the second order elements where there is complex contact in the model. In order to simulate the motion of the copper sample inside of the die, displacement or velocity type boundary conditions could be used. However, the velocity type boundary condition is assigned as this type of boundary condition obtains much smoother runs. Figure 4 indicates the finite element model of the present study for two channel ECAP process. 

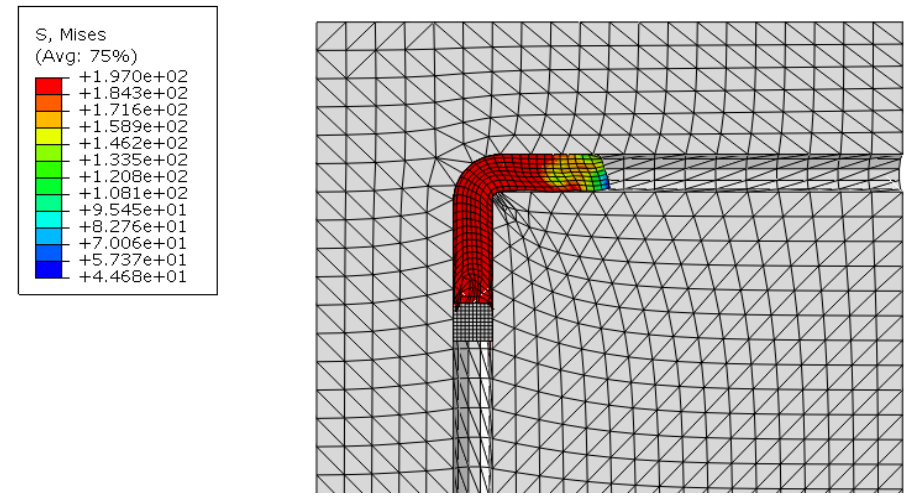

Figure 4:

The finite element model of the two channel ECAP process.

\section{RESULTS AND DISCUSSION}

At the working pressures of ECAP process, the $\mathrm{SiO} 2$ powder or other solid lubricants cannot be effective (Miavaghi, et. al. 2017), because the contact pressure between the copper sample and steel die is higher than the copper yield strenght. The friction regime in ECAP process of this study was dry friction. The copper is soft and the steel is brittle materials, therefore, the friction mechanism between sample-die in this process can be considred as soft-brittle regime as disscussed by Miavaghi et. al. (2017). In soft-brittle friction regimes the dominant friction mechanism is ploughing type (Jivan et. al. 2021). The coeffient of friction for this mechanism is typically high. The total friction in ECAP process is a function of sample and die material types, sample length and diameter. In order to make valid comparision among different experimental tests during the tests all friction influencing parameters kept constant.

Figure 5 shows the results of the measured punching forces during the two channels ECAP process. As it is clear, the required force gradually increased with time elapsing to overcome the shear strength of the sample and the frictional force at the entrance channel. By further processing the sample started to enter the exit channel and afterward the required punching force stayed almost constant. This trend was credible for the first and second passes. However, there was a great difference in the amount of the required punching force on the first and second stages. This is due to the fact that after the first pass the sample strengthened due to work hardening.

Figure 6 indicates that the trend was changed for the one channel ECAP process in comparison with two channel ECAP process. In this state the required punching force increased until overcoming the shear strength of the sample, touched the peak value and started to decrease gradually. This is because that in one channel ECAP process, there is no friction forces in the second channel and by any displacement of the punch, more length of the sample exit from the entrance channel to the air and in contradictory with the two channels ECAP process the total contact length of the sample decreases. Furthermore, the results revealed that in the one channel ECAP process there was no significant difference between the required forces for the first and second passes (Figure 6). The possible reason for this phenomenon is that, during processing with the one channel ECAP die, the full refinement of the sample could not occur and consequently the sample could not show considerable mechanical improvement after the first pass. 


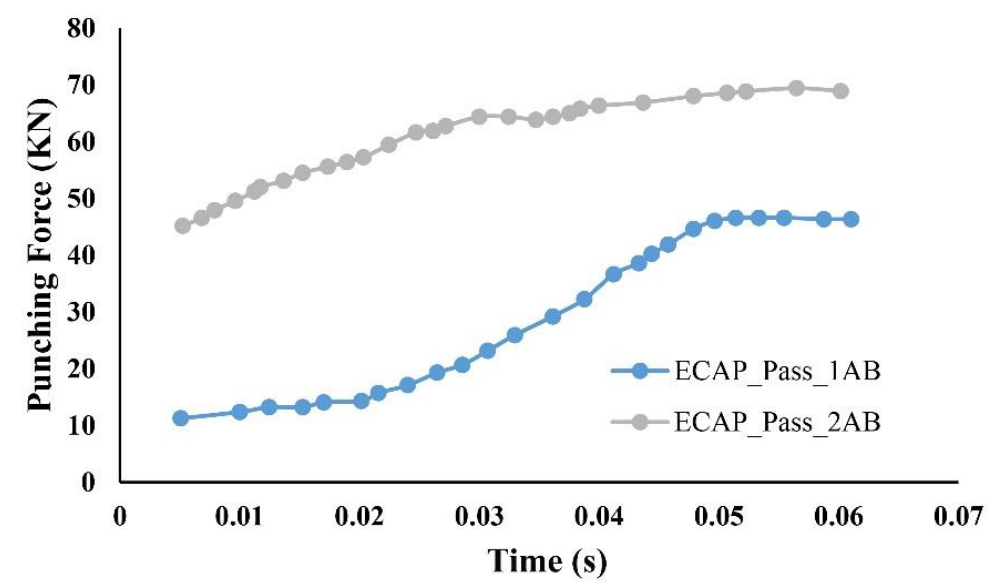

Figure 5:

Variation of the punching force within the ECAP process using the two channels ECAP die.

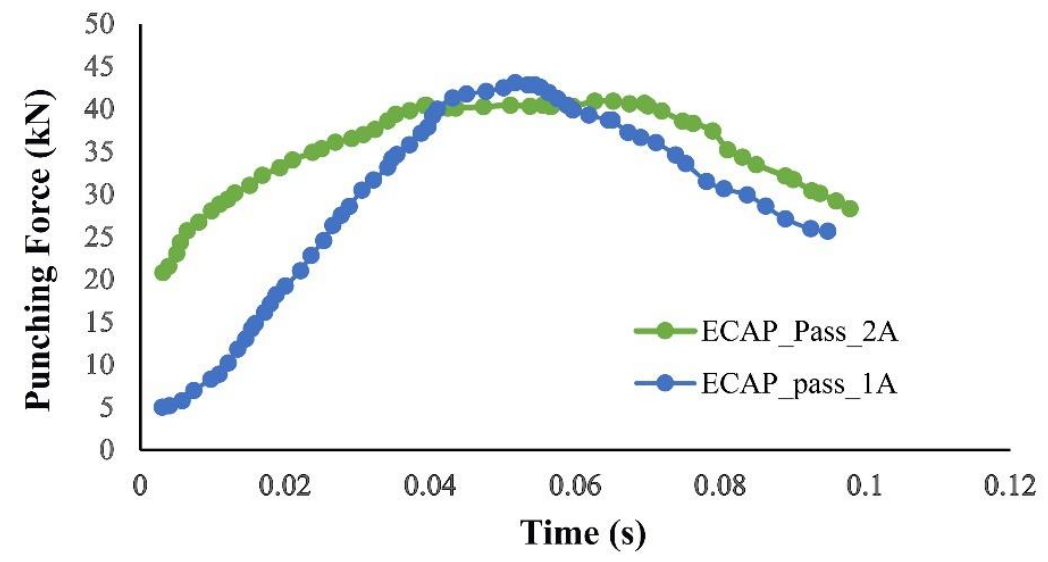

Figure 6:

Variation of the punching force in one channel ECAP process.

It should be noted that microstructural grain refinement at the ECAP passes increases the yield strength of the sample and accordingly, the required force to shape the sample in subsequent passes increaes. This issue was investigated by optical microscopy. The images of the processed samples were shown in Figure 7. It is clear from the micrographs that the grain size of the processed samples using the two channels ECAP method was finer than that of the one channel ECAP process, which confirmed the aforementioned hypotheses. 

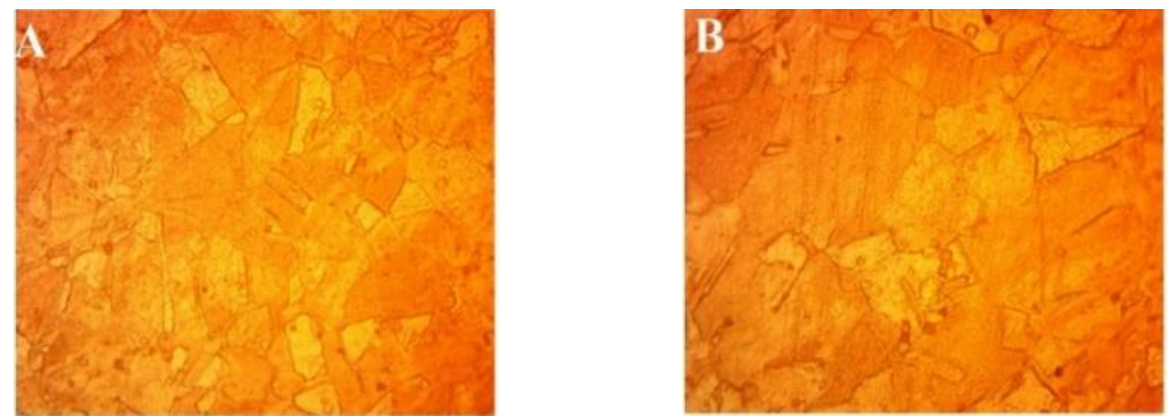

Figure 7:

Optical microscopy images of the processed sample using (A): two channels ECAP; (B): One channel ECAP die.

The comparison of the results for the required punching force in the first pass for the two dies was presented in Figure 8. As it is obvious, the maximum required punching force in twochannel ECAP process was about $12 \%$ higher than that of the one channel ECAP process. Accordingly, it can be concluded that the friction in the exit channel constitute about $12 \%$ of the total required force in ECAP processes.

The variations in punching force of two dies are even higher in the second pass (Figure 9). According to Figure 9, the required punching force for the two ECAP dies had substantial differs and the values for the two-channel die showed obvious high values, even at the beginning of the process.

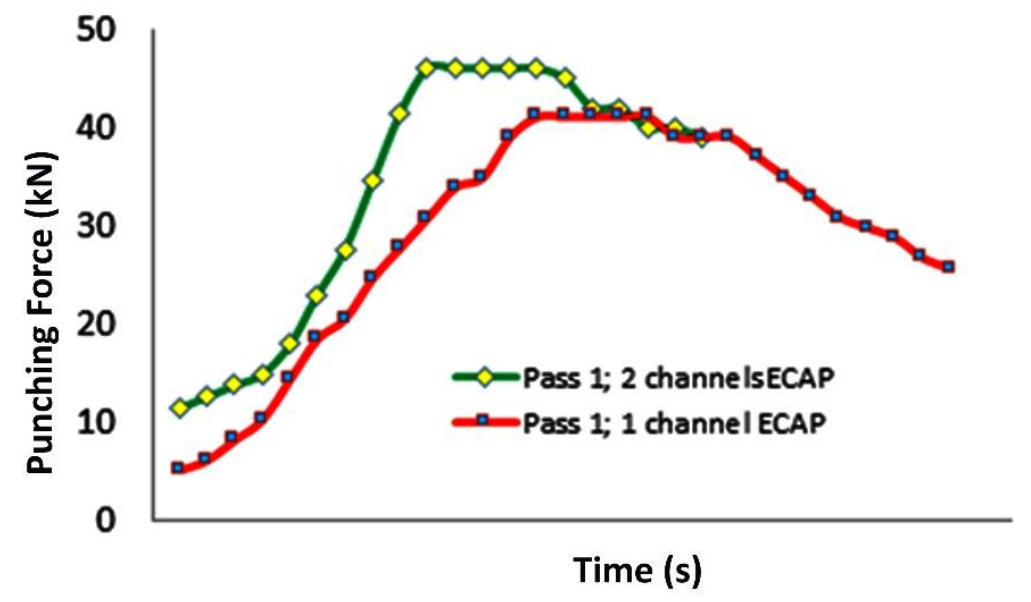

Figure 8:

Comparison of the required punching force in the ECAP dies with and without the exit channel (at the first pass). 


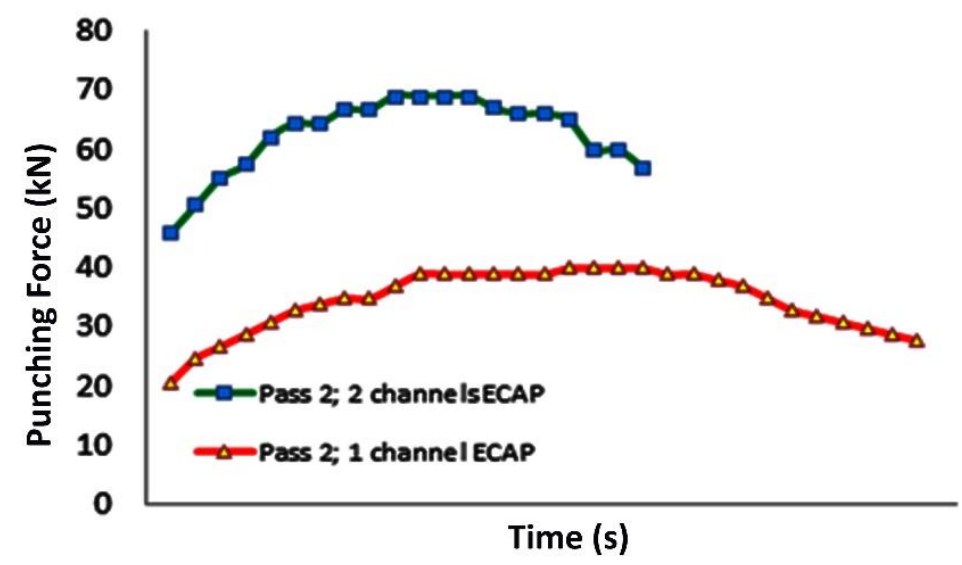

Figure 9:

Comparison of the required punching force in the ECAP dies with and without the exit channel (at the second pass).

The same trends with experimental tests were obtained from finite element modelling. Figure 10 shows the comparison of the required punching forces for one channel and two channels ECAP dies. Although the required punching forces are not coincide with experimental tests, but the trends are similar. The reason for discripancy between the required forces obtained from experimental tests and FEM analysis may be refered to the used coefficient of friction in FEM analysis and the real coefficient of friction in experiments.

According to Figure 10 the required punching force in two-channel ECAP process was higher than that of for one-channel ECAP process and the trend is in compliance with Figure 5. As it is obvious from Figure 11, in the absence of frictional forces in the second channel (in onechannel ECAP), the frictional dissipation for one-channel ECAP process was lower than that of for two-channel ECAP process throughout the run.

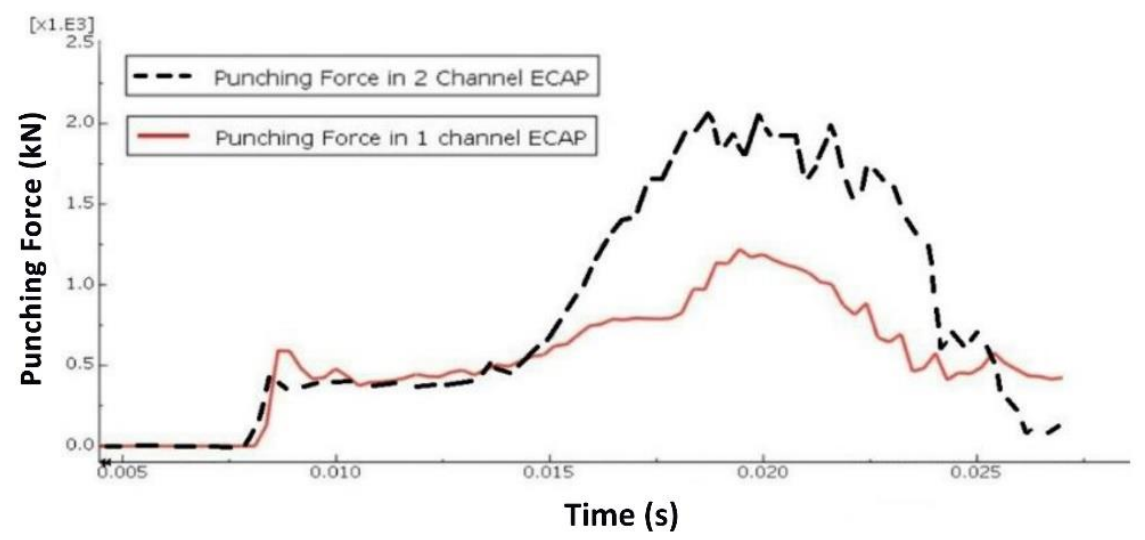

Figure 10:

Comparison of the required punching force in the ECAP dies with and without the exit channel (at the first pass) (results from finite element modelling). 


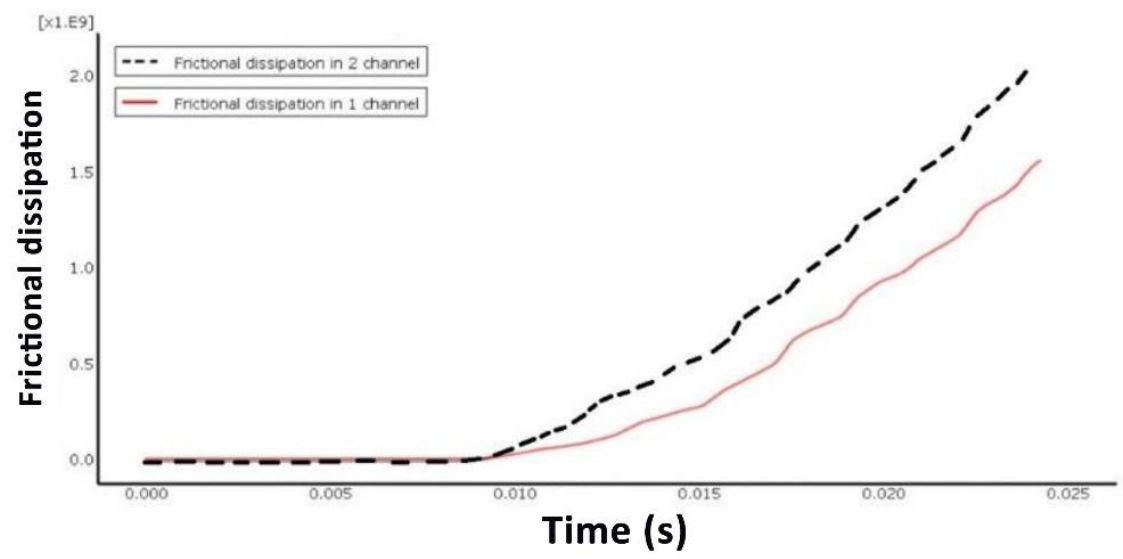

Figure 11:

Frictional dissipation in both 1 channel and 2 channel die

In addition to differences in the punching force and grain refinement rates, the geometry of the final processed sample in two-channel ECAP die was significantly different from the sample produced in one-channel ECAP die. While the diameter of the finally produced sample using twochannel ECAP die was approximately equal to the diameter of the die hole itself; the final diameter of the sample produced by the one-channel ECAP die was about $0.1 \mathrm{~mm}$ larger than the die hole. Furthermore, unlike to the two-channel ECAP process, the final product in the onechannel ECAP had some deformations along its length. As it is illustrated in Figure 12, this deformation was observed in both experiments and finite element visualization.

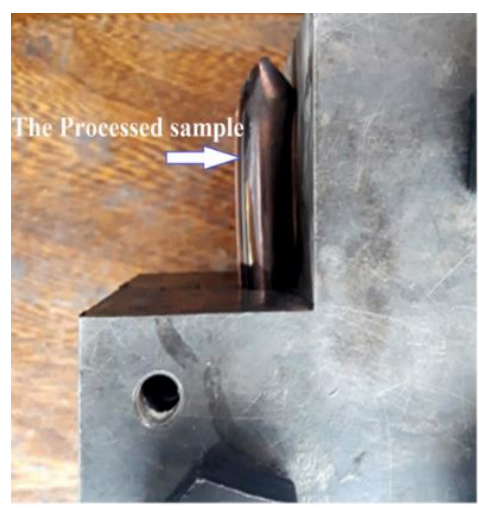

a.

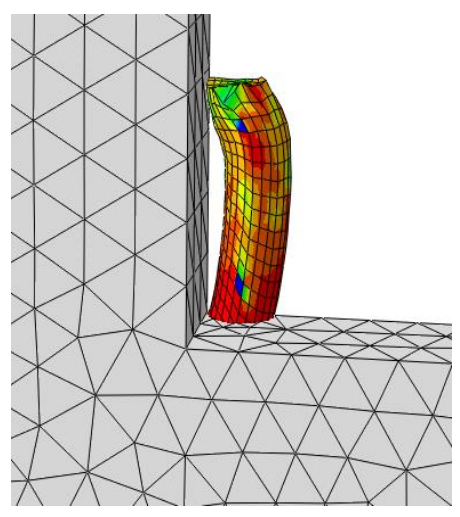

$b$.

Figure 12:

Shows the deformation of the sample when processed using one-channel ECAP die;

a. Experiment b. FEM simulation

\section{CONCLUSIONS}

Through this paper, the effect of an exit channel in amount of the frictional losses, punching force, grain refinement and sample geometry were investigated experimentally and numerically. According to experimental measurements, the friction force in the exit channel of an AISI 4340 
carbon steel die during copper sample processing is about $12 \%$ of the total punching force. The same trend was obtained from finite element simulation. In addition, the results of the microstructural investigation using optical microscopy were indicated that the rate of grain size refinement in ECAP die was considerably reduced when using one-channel die. It means that, although the second channel increases the friction forces, however, it has advantageous of helping in grain refinement process. Furthermore, visual inspection of the final products indicated that, the geometry of the sample shows some deflections when processing using one-channel ECAP die. This deflection also observed in finite element modelling.

\section{CONFLICT OF INTEREST}

There is not any conflict of interest concerning the stages of data collection and analysis, interpretation of results and writing during the preparation of the manuscript.

\section{AUTHOR CONTRIBUTION}

Mehdi Eskandarzade determining the concept and design process of the research and research management, Meysam Najafi Ershadi data collection and analysis, data analysis and interpretation of results.

\section{REFERENCES}

1. Agarwal, K. M., Tyagi, R. K. and Kapoor, A. (2020) Deformation and strain analysis for grain refinement of materials processed through equal channel angular pressing, Materials Today: Proceedings, 21, 1513-1519. doi: 10.1016/j.matpr.2019.11.072.

2. Agwa, M., Ali, M. and Al-Shorbagy, A. E. (2016) Optimum processing parameters for equal channel angular pressing, Mechanics of Materials, 100, 1-11. doi: 10.1016/j.mechmat.2016.06.003.

3. Balasundar, I. and Raghu, T. (2010) Effect of friction model in numerical analysis of equal channel angular pressing process, Materials \& Design, 31(1), 449-457. doi: 10.1016/j.matdes.2009.05.029.

4. Cai, G. Y., Huang, X. T. and Zhang, S. X. (2011) Finite Element Simulation of Effects of Mould Angle and Friction on ECAP for AZ80 Magnesium Alloy, Materials Science Forum, 667, 81-86. doi: 10.4028/www.scientific.net/MSF.667-669.81.

5. Djavanroodi, F. and Ebrahimi, M. (2010) Effect of die channel angle, friction and back pressure in the equal channel angular pressing using 3D finite element simulation, Materials Science and Engineering: A, 527(4-5), 1230-1235. doi: 10.1016/j.msea.2009.09.052.

6. Djavanroodi, F., Ahmadian, H., Koohkan, K. and Naseri, R. (2013) Ultrasonic assistedECAP, Ultrasonics, 53(6) 1089-1096. doi: 10.1016/j.ultras.2013.02.003.

7. Dumoulin, S., Roven, H., Werenskiold, J. and Valberg, H. (2005) Finite element modeling of equal channel angular pressing: Effect of material properties, friction and die geometry, Materials Science and Engineering: A, 410, 248-251. doi: 10.1016/j.msea.2005.08.103.

8. Eivani, A. and Taheri, A. K. (2008) The effect of dead metal zone formation on strain and extrusion force during equal channel angular extrusion, Computational Materials Science, 42(1), 14-20. doi: 10.1016/j.commatsci.2007.06.001. 
9. Eskandarzade, M., Masoumi, A. and Faraji, G. (2016) Numerical and analytical investigation of an ultrasonic assisted ECAP process, Journal of Theoretical and Applied Vibration and Acoustics, 2(2), 167-184. doi: 10.22064/TAVA.2016.22472.

10. Eskandarzade, M., Masoumi, A., Faraji, G., Mohammadpour, M. and Yan, X.S. (2017) A new designed incremental high pressure torsion process for producing long nanostructured rod samples, Journal of Alloys and Compounds, 695(3) 539-1546. doi: 10.1016/j.jallcom.2016.10.296

11. Higuera-Cobos, O. F. and Cabrera, J. M. (2013) Mechanical, microstructural and electrical evolution of commercially pure copper processed by equal channel angular extrusion, Materials Science and Engineering: A, 571, 103-114. doi: 10.1016/j.msea.2013.01.076.

12. Jivan, R.B., Eskandarzade, M., Bewsher, S.R., Leighton, M., Mohammadpour, M., SaremiYarahmadi, S. (2021) Application of Solid Lubricant for Enhanced Frictional Efficiency of Deep Drawing Process, Proceedings of the Institution of Mechanical Engineers, Part C: Journal of Mechanical Engineering Science, article in press, doi: $10.1177 / 0954406221994886$

13. Ko, Y. and Shin, D. (2011) Microstructure and mechanical properties of nanostructured lowcarbon steel prepared by equal-channel angular pressing, Nanostructured Metals and Alloys: Elsevier, 243-275. doi: 10.1533/9780857091123.2.243.

14. Miavaghi, A.S., Kangarlou, H. and Eskandarzade, M. (2017) Comparison Between Frictional Behavior of the Soft and Brittle Materials at Different Contact Pressures, Lebanese Science Journal, 18(1), 98-105. doi: 10.22453/LSJ-018.1.098105

15. Nagasekhar, A., Yoon, S., Tick-Hon, Y. and Kim, H. (2009) An experimental verification of the finite element modelling of equal channel angular pressing, Computational materials science, 46(2), 347-351. doi: 10.1016/j.commatsci.2009.03.018.

16. Patil, B. V., Chakkingal, U. and Kumar, T. P. (2008) Influence of friction in equal channel angular pressing-A study with simulation, in Proceedings of the 17th International Conference of Metallurgy and Materials (Metal 2008), Czech Rep.

17. Riazat, M. and Faraji, G. (2015) Size effect in equal channel angular pressing (ECAP) process, Journal of Advanced Materials and Processing, 3(3), 3-12.

18. Salleh, M., Ishak, N., Yahaya, S. and Abdullah, A. (2018) Effect of equal channel angular pressing on the microstructure and mechanical properties of a356 alloy, Journal of Advanced Manufacturing Technology (JAMT), 12(2), 79-92.

19. Souza, V. A., Watanabe, I. and Yanagida, A. (2016) Numerical Estimation of Frictional Effects in Equal Channel Angular Extrusion, Materials transactions, 57(9), 1399-1403. doi: 10.2320/matertrans.MH201513.

20. Taşdelen, M. and Yılmaz, İ. (2018) Cam Elyaf Katkı11 Poliamid 66/Poliftalamid Karışımlarının Hazırlanması . Uludağ University Journal of The Faculty of Engineering, 23(1), 285-294 . doi: 10.17482/uumfd.350589.

21. Ulutan, M., Celik, O. N., Gasan, H. and Er, U. (2010) Effect of Different Surface Treatment Methods on the Friction and Wear Behavior of AISI 4140 Steel, Journal of Materials Science \& Technology, 26(3), 251-257. doi: 10.1016/S1005-0302(10)60042-4.

22. Valiev, R. Z. and Langdon, T. G. (2006) Principles of equal-channel angular pressing as a processing tool for grain refinement, Progress in materials science, 51(7), 881-981. doi: 10.1016/j.pmatsci.2006.02.003. 
23. Xu, S., Zhao, G., Ren, G. and Ma, X. (2008) Numerical simulation and experimental investigation of pure copper deformation behavior for equal channel angular pressing/extrusion process, Computational Materials Science, 44(2), 247-252. doi: 10.1016/j.commatsci.2008.03.032.

24. Yoon, S. C., Seo, M. H., Krishnaiah, A. and Kim, H. S. (2008) Finite element analysis of rotary-die equal channel angular pressing, Materials Science and Engineering: A, 490(1-2), 289-292. doi: 10.1016/j.msea.2008.01.037. 
